\title{
Pathogen-induced Chemokine Secretion from Model Intestinal Epithelium is Inhibited by Lipoxin $A_{4}$ Analogs
}

\author{
Andrew T. Gewirtz, ${ }^{\star}$ Beth McCormick, ${ }^{\ddagger}$ Andrew S. Neish, ${ }^{\star}$ Nicos A. Petasis, ${ }^{\S}$ Karsten Gronert,, Charles N. Serhan, \\ and James L. Madara* \\ *Department of Pathology and Laboratory Medicine, Emory University, Atlanta, Georgia 30322; ${ }^{\ddagger}$ Department of Gastroenterology, \\ Massachusetts General Hospital, Boston, Massachusetts 02114; ${ }^{\S}$ Department of Chemistry, University of Southern California, \\ Los Angeles, California 90089; and ${ }^{\|}$Center for Experimental Therapeutics and Reperfusion Injury, Brigham and Women's Hospital, \\ Harvard Medical School, Boston, Massachusetts 02115
}

\begin{abstract}
Enteric pathogens induce intestinal epithelium to secrete chemokines that direct movement of polymorphonuclear leukocytes. Mechanisms that might downregulate secretion of these proinflammatory chemokines and thus contain intestinal inflammation have not yet been elucidated. The antiinflammatory activities exhibited by the arachidonate metabolite lipoxin $\mathrm{A}_{4}$ ( $\mathrm{LXA}_{4}$ ) suggests that this eicosanoid, which is biosynthesized in vivo at sites of inflammation, might play such a role. We investigated whether chemokine secretion could be regulated by stable analogs of $\mathrm{LXA}_{4}$. Monolayers of T84 intestinal epithelial cells were infected with Salmonella typhimurium, which elicits secretion of distinct apical (pathogen-elicited epithelial chemoattractant) and basolateral (IL-8) chemokines. Stable analogs of LXA $_{4}$ inhibited $S$. typhimurium-induced (but not phorbol esterinduced) secretion of both IL-8 and pathogen-elicited epithelial chemoattractant. $\mathrm{LXA}_{4}$ stable analogs did not alter bacterial adherence to nor internalization by epithelia, indicating that $\mathrm{LXA}_{4}$ stable analogs did not block all signals that Salmonella typhimurium activates in intestinal epithelia, but likely led to attenuation of signals that mediate chemokine secretion. Inhibition of $S$. typhimurium-induced IL-8 secretion by $\mathrm{LXA}_{4}$ analogs was concentration- ( $\left.\mathrm{IC}_{50} \sim 1 \mathrm{nM}\right)$ and time-dependent (maximal inhibition $\sim 1 \mathrm{~h}$ ). As a result of these effects, LXA $_{4}$ stable analogs inhibited the ability of bacteria-infected epithelia to direct polymorphonuclear leukocyte movement. These data suggest that $\mathrm{LXA}_{4}$ and its stable analogs may be useful in downregulating active inflammation at mucosal surfaces. (J. Clin. Invest. 1998. 101:18601869.) Key words: IL-8 • Salmonella • neutrophil • transmigration • inflammation $\bullet$ chemokine
\end{abstract}

\section{Introduction}

The intestinal epithelium, in addition to being an entry point for many invasive pathogens, is also an active participant in the inflammatory response due to immune and other causes. Epi-

Address correspondence to Andrew Gewirtz, Department of Pathology and Laboratory Medicine, WMRB 2315, Emory University Hospital, Atlanta, GA 30322. Phone: 404-727-8537; FAX: 404-727-8538; E-mail: agewirt@emory.edu

J. Clin. Invest.

(C) The American Society for Clinical Investigation, Inc. 0021-9738/98/05/1860/10 \$2.00

Volume 101, Number 9, May 1998, 1860-1869

http://www.jci.org thelial cell signaling pathways that are activated by some invasive bacteria such as Salmonella typhimurium mediate uptake of these pathogens into these usually nonphagocytic cells (1, 2). After internalization of the bacteria, the intestinal epithelium secretes chemokines $(3,4)$ that play a role in recruiting PMN from the peripheral circulation and directing them to transmigrate across the epithelium to the intestinal lumen (5). Epithelial modulation of PMN movement is thought to be mediated by polarized secretion of distinct chemokines. IL-8 is secreted basolaterally by intestinal epithelial cell lines and human colon in response to proinflammatory cytokines or invasive bacteria (6). This secretion leads to gradients of IL-8 that are chemotactic for neutrophils being formed in the subepithelial extracellular matrix (7). These gradients of IL-8 have been shown to be largely responsible for PMN movement through the extracellular matrices of model epithelia (7). The chemokines that direct neutrophil transmigration across the intestinal epithelial monolayer are only now being described. These chemokines must be preferentially secreted apically in order to establish gradients that would direct PMN to migrate across the epithelium to the apical surface. The first such chemokine, pathogen-elicited epithelial chemoattractant (PEEC; 8), has recently been described. As the ability of bacteria to induce PEEC secretion in model intestinal epithelia (and subsequently to induce the epithelium to direct PMN to transmigrate) appears to correlate well with a bacteria's ability to cause enteritis in humans $(5,8)$, secretion of PEEC, like secretion of IL-8, appears to be an important proinflammatory event.

Epithelial recruitment of PMN in response to detection of luminal pathogens may play a role in host defense against some pathogens. In contrast, chronic inflammatory diseases are characterized by acute flares defined by neutrophil-epithelial interactions that are responsible for the majority of clinical symptoms, but occur in the absence of any known pathogen (9). The acute flares of such chronic inflammatory states (i.e., Crohn's disease, ulcerative colitis) might thus result from aberrant activation of epithelial proinflammatory pathways. If so, such flares and the symptoms that result from them could perhaps be alleviated by downregulating epithelial secretion of chemokines. That intestinal inflammation is normally self-limiting suggests that mechanisms downregulating inflammation exist in intestinal epithelia, although they are only now beginning to be described. A class of molecules that is a suitable candidate for involvement in activating antiinflammatory sig-

1. Abbreviations used in this paper: EPEC, enteropathogenic Escherichia coli; LO, lipoxygenase; LX, lipoxin; PEEC, pathogen-elicited epithelial chemoattractant. 
naling pathways, and hence downregulating intestinal inflammation, is the lipoxins (LX). Lipoxins are produced from arachidonate by the combined actions of 5-lipoxygenase (LO) and 12 -LO or 15-LO (for review see reference 10). While the biological behavior of lipoxins, when tested in various experimental systems, includes vasoregulatory and immunoregulatory actions, the general profile of lipoxin behavior appears to be emerging as antiinflammatory, particularly in respect to neutrophil motility. One lipoxin in particular, $\mathrm{LXA}_{4}$, has an array of antiinflammatory actions, including inhibition of leukocyte diapedesis in the microcirculation of the hamster cheek pouch (11), depressing contraction of the guinea pig ileum (12), and inhibition of PMN migration across model endothelium (13) and epithelium (14). Synthetic analogs of $\mathrm{LXA}_{4}$ exhibit greater antiinflammatory activity than does native $\mathrm{LXA}_{4}$, probably because they are more resistant to degradation than the native eicosanoid (15). One stable analog of $\mathrm{LXA}_{4}, 15(\mathrm{R} /$ $\mathrm{S})$-methyl-LXA $\mathrm{L}_{4}$, also closely resembles 15 -epi-LXA $\mathrm{LA}_{4}$ that is synthesized in vivo in the presence of aspirin (16), and may be responsible for some of the therapeutic effects of this commonly used nonsteroidal antiinflammatory agent.

LX inhibition of PMN transepithelial migration requires that both the PMN and the epithelial cells be exposed to the lipoxins (14). It remained to be determined whether LX in the absence of leukocytes had a direct effect on epithelial cells. Here, using monolayers of T84 cells, S. typhimurium, and human neutrophils to model pathogen-induced intestinal inflammation, we report that epithelia respond functionally to $\mathrm{LXA}_{4}$ analogs by exhibiting attenuated basal and pathogen-induced epithelial cell chemokine/chemoattractant secretion. This novel action of $\mathrm{LXA}_{4}$ and its stable analogs resulted in attenuated PMN migration across model epithelia.

\section{Methods}

Materials. Lipoxin $\mathrm{A}_{4}$ and lipoxin $\mathrm{B}_{4}$ were obtained from Cascade Biochem (Reading, Berkshire, United Kingdom). Lipoxin $\mathrm{A}_{4}$ analogs

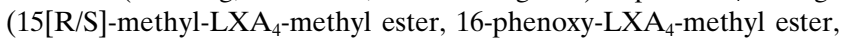
15-deoxy-LXA ${ }_{4}$-methyl ester) and 15-epi-LXA ${ }_{4}$-methyl ester were prepared by total organic synthesis, and their structures were confirmed by HPLC, NMR, and mass spectral analysis (15). Daily working stocks of lipoxin $(100 \mu \mathrm{M})$ concentrations were verified by UV spectroscopy using a molar extinction coefficient of $50,000 \mathrm{~cm}^{-1} \mathrm{M}^{-1}$, $\lambda \underset{\max }{\mathrm{MeOh}}=301 \mathrm{~nm}$. These solutions were stored at $-70^{\circ} \mathrm{C}$ in $99 \%$ ethanol. S. typhimurium $\left(\mathrm{x}_{3306}\right)$ was cultured as previously described (3). Enteropathogenic Escherichia. coli (EPEC) received from G. Hecht (University of Illinois, Chicago, IL) was cultured as previously described (17).

Salmonella typhimurium-induced IL-8 secretion. Unless otherwise indicated in figure legend, the following procedure was used. Confluent monolayers of T84 cells, grown on $0.33-\mathrm{cm}^{2}$ collagen-coated permeable supports (resistance $>600 \Omega \times \mathrm{cm}^{2}$ ), were washed three times with HBSS and placed into $300 \mathrm{ml}$ of HBSS that contained 100 nM LX or vehicle (always $0.1 \%$ ethanol). The time from which LXcontaining HBSS was prepared and T84 cells being placed into it was never $>3 \mathrm{~min}$. $60 \mathrm{~min}$ later, monolayers were placed in empty wells, and $25 \mu \mathrm{l}$ of $S$. typhimurium-containing HBSS $\left(1.6 \times 10^{10}\right.$ bacteria/ $\mathrm{ml})$ was placed on the apical surface of each monolayer. This inoculum has been previously shown to correspond to 30 associated bacteria per T84 cell (3). 45 min later, the monolayers were returned to the same LX-containing HBSS in which they had been incubated before adding S. typhimurium. Antibiotics were not used (except in separate experiments measuring bacterial internalization, as described below). $5 \mathrm{~h}$ after adding the bacteria, T84 cell supernatants were removed and assayed for IL-8. IL-8 was measured by ELISA as previously described (3) except for a few minor modifications: 96-well plates (Linbro/Titretek; ICN Biomedicals, Costa Mesa, CA) were coated overnight with goat $\alpha$-human IL-8 (R \& D Systems, Inc., Minneapolis, $\mathrm{MN}$ ), and the detecting antibody used was rabbit $\alpha$-human IL-8 (Endogen, Inc., Woburn, MA). When Caco-2 BBE cells were used, the entire experiment was performed in culture media (DMEM supplemented with $10 \%$ FCS) because we did not observe detectable IL-8 secretion in response to $S$. typhimurium in these cells when the experiment was performed in HBSS.

Salmonella typhimurium internalization assay. S. typhimurium adherence to and internalization by T84 cell monolayers was measured as previously described (3). Replication of internalized bacteria was assessed by adding a 4 - $\mathrm{h}$ incubation at $37^{\circ} \mathrm{C}$ after noninternalized bacteria were killed by a 1 -h incubation with gentamicin $(500 \mathrm{mg} / \mathrm{ml})$. Relative in vitro growth of $S$. typhimurium was measured by inoculating $10 \mathrm{ml}$ of Luria broth $( \pm 100 \mathrm{nM} 15 \mathrm{R} / \mathrm{S}$-methyl-LXA 4 ) with $0.01 \mathrm{ml}$ of a stationary phase bacterial culture and measuring OD at $405 \mathrm{~nm} 5 \mathrm{~h}$ after inoculation.

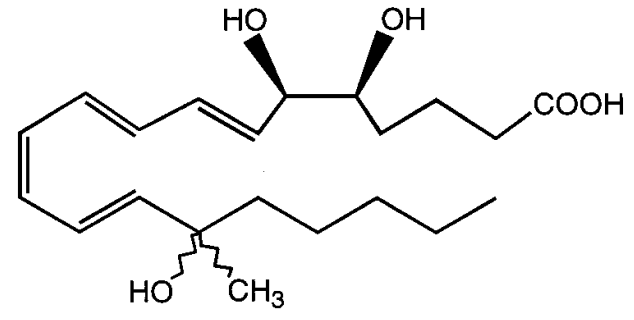

15(R/S)-methyl-LXA
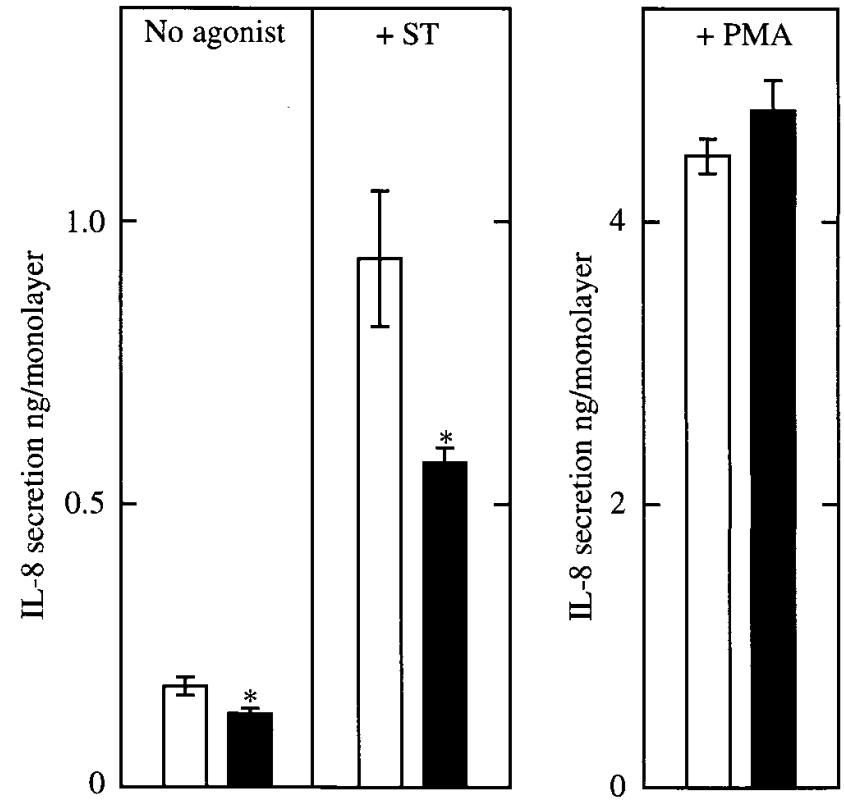

Figure 1. Lipoxin $\mathrm{A}_{4}$ stable analog attenuates IL-8 secretion from model intestinal epithelia. Monolayers of T84 cells were incubated in $100 \mathrm{nM} 15(\mathrm{R} / \mathrm{S})$-methyl-LXA 4 (shown above) or vehicle (0.1\% ethanol) for $1 \mathrm{~h}$ before being treated with buffer (no agonist), S. typhimurium $(S T)$, or PMA $(1 \mathrm{ng} / \mathrm{ml}) .5 \mathrm{~h}$ later, basolateral supernatants were assayed for IL-8. Open bars, control (vehicle). Solid bars, $+100 \mathrm{nM}$ 15(R/S)-methyl-LXA ${ }_{4}$. Data are the means \pm SEM of six monolayers/ condition from one experiment, and are representative of four separate experiments. 
PEEC isolation. Confluent $5-\mathrm{cm}^{2}$ monolayers of T84 cells were washed three times with HBSS and placed into $1.5 \mathrm{ml}$ of HBSS that contained $1 \mathrm{nM} 15(\mathrm{R} / \mathrm{S})$-methyl-LXA ${ }_{4}$ or vehicle ( $0.1 \%$ ethanol). 60 min later, $1 \mathrm{ml}$ of HBSS containing $S$. typhimurium $\left(1.6 \times 10^{10}\right.$ bacte$\mathrm{ria} / \mathrm{ml}$ ) and $1 \mathrm{nM} 15(\mathrm{R} / \mathrm{S})$-methyl-LXA 4 or vehicle was placed on the apical surface of each monolayer. $45 \mathrm{~min}$ later, the monolayers were washed three times with HBSS to remove nonadherent bacteria, and were placed into $300-\mu \mathrm{l}$ fresh HBSS. $4 \mathrm{~h}$ later, T84 cell apical supernatants were removed, and PEEC was isolated, partially purified by collecting the filtrate over a $1-\mathrm{kD}$ cutoff filter, and concentrated 50 fold (8). We verified that statistically significant amounts of $15(\mathrm{R} / \mathrm{S})$ methyl-LXA ${ }_{4}$ were not present in these PEEC isolates by measuring the LX concentrations of solutions before and after they passed over the $1-\mathrm{kD}$ cutoff filters.

Assay for PEEC concentration by measuring its ability to drive $P M N$ transepithelial migration. Virgin (i.e., not exposed to S. typhimurium or LX) confluent T84 inverted monolayers were washed three times in HBSS before $300 \mu$ of PEEC (in HBSS) isolated from vehicle (control) or LX-treated $S$. typhimurium-infected T84 monolayers were placed in their apical (bottom) reservoir. $2 \times 10^{6} \mathrm{PMN}$ were then placed in the basolateral reservoir and allowed $2 \mathrm{~h}$ (at $37^{\circ} \mathrm{C}$ ) to transmigrate. The number of PMN that had migrated to the basolateral reservoir was measured enzymatically as previously described (18).
Assay for PEEC concentration by measuring its ability to induce cytoplasmic $\left[\mathrm{Ca}^{++}\right]$changes in PMN. PMN were loaded with the calcium indicator Indo-1 and cytoplasmic $\left[\mathrm{Ca}^{++}\right]$measured as previously described $(19,20)$ using a Hitachi F-4500 spectrofluorometer. PMNs $\left(2 \times 10^{6}\right)$ were suspended in $960 \mu l$ of HBSS and stimulated with 40 $\mu \mathrm{l}$ of 50 -fold concentrated PEEC (final PEEC concentration $=2 \times$ that found in apical supernatants).

Measurement of IL-8 $m R N A$. T84 monolayers $\left(5 \mathrm{~cm}^{2}\right)$ were treated with indicated lipoxin or vehicle ( $0.1 \%$ ethanol) and infected with $S$. typhimurium as described above. At the indicated time after adding the bacteria, RNA was extracted. IL-8 mRNA and actin mRNA as a control were then analyzed by Northern blot as previously described (21). Film was scanned, densitometry was measured via National Institutes of Health image, and relative IL- 8 was quantitated by normalizing to actin mRNA levels.

Salmonella typhimurium-induced PMN transepithelial migration and matrix imprinting. Inverted monolayers were treated with 100 $\mathrm{nM}$ 15(R/S)-methyl-LXA ${ }_{4}$ for $1 \mathrm{~h}$ and infected with $S$. typhimurium as described above. S. typhimurium-induced PMN transepithelial migration and matrix imprinting were then measured as previously described (7).

Data analysis. Because absolute values of IL-8 and PEEC secretion vary with T84 cell passage number, the effects of lipoxins on T84 monolayer secretion of these chemokines are displayed as either the

a
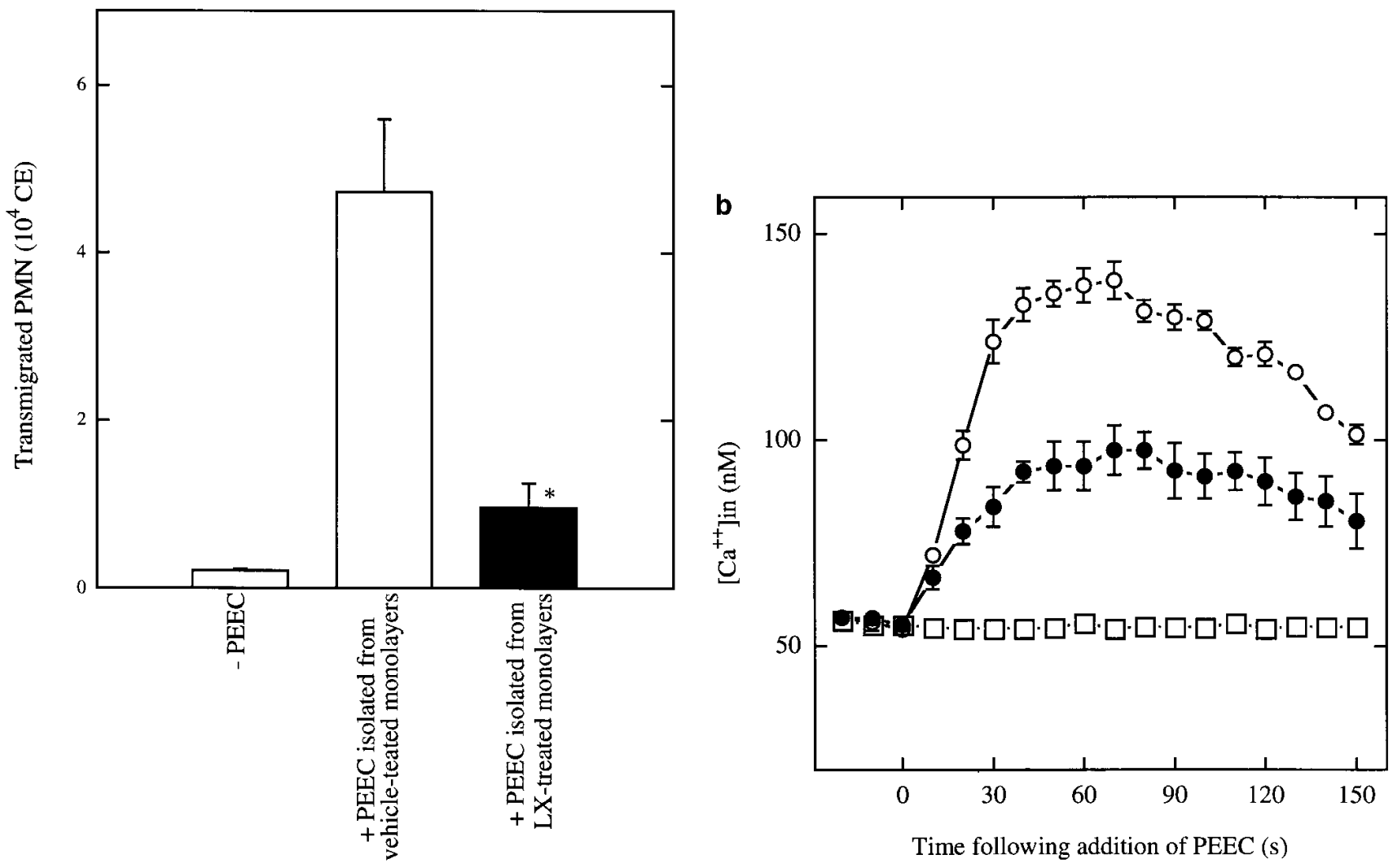

Figure 2. Lipoxin $\mathrm{A}_{4}$ stable analog inhibits $S$. typhimurium-induced PEEC secretion. Inverted monolayers of T84 cells were incubated in $1 \mathrm{nM}$ $15(\mathrm{R} / \mathrm{S})$-methyl-LXA 4 or vehicle $(0.1 \%$ ethanol) for $1 \mathrm{~h}$ before adding $S$. typhimurium. $1 \mathrm{~h}$ later, nonadherent $S$. typhimurium was washed off, and PEEC was isolated from the apical supernatants that were collected over the following $2 \mathrm{~h}$. (a) PEEC, concentrated 50-fold from apical supernatants, was placed in the apical reservoir of T84 monolayers, and its ability to induce PMN when placed in the basolateral reservoir to transmigrate was measured. (b) Indo-1-loaded PMN $\left(2 \times 10^{6} / \mathrm{ml}\right)$ were suspended in HBSS while their cytoplasmic [Ca ${ }^{++}$] was measured continuously by spectofluorimetry. PEEC was added at a final concentration equal to twice that found in the apical supernatants of $S$. typhimuriuminfected T84 cells. $\square$, No PEEC; $\bigcirc,+$ PEEC isolated from S. typhimurium-infected control monolayers; $\bullet$, PEEC isolated from S. typhimurium-infected LX-treated monolayers. PEEC isolates were pooled from three separate experiments, each using five monolayers per condition. These data are the means of a triplicate analysis \pm SEM of the pooled isolates. 
results from a representative experiment or as a percent of control (vehicle) values. Additionally, there is variability in the way PMN from different donors transmigrate in response to PEEC, explaining why absolute numbers of transmigrated PMN vary between experiments. Statistical significance was assessed using Student's $t$ test. ${ }^{*} P<$ 0.05 when compared with control.

\section{Results}

To investigate whether lipoxins (LX) could affect epithelial chemokine secretion, model intestinal epithelia (i.e., confluent monolayers of T84 cells) were exposed to vehicle ( $0.1 \%$ ethanol) or a stable analog of $\mathrm{LXA}_{4}$ and then infected with a pathogenic strain of $S$. typhimurium. $5 \mathrm{~h}$ after exposure to the bacteria, basolateral supernatants of the monolayers were assayed for IL-8, as this chemokine is known to be preferentially secreted to that surface. Noninfected monolayers exhibited a relatively low level of IL-8 secretion that was mildly inhibited (5-20\% inhibition in several different experiments) by $15(\mathrm{R} / \mathrm{S})$ methyl-LXA 4 (Fig. 1), while $S$. typhimurium infection led to much greater IL- 8 secretion that was inhibited $\sim 50 \%$ by this stable LXA $_{4}$ analog (Fig. 1). Importantly, IL-8 secretion induced by PMA, a known potent but nonphysiologic activator of IL-8 secretion, was not inhibited by $15(\mathrm{R} / \mathrm{S})$-methyl-LXA (Fig. 1), suggesting that $\mathrm{LXA}_{4}$ analogs did not affect the ability of T84 cells to secrete IL- 8 , but rather may have downregulated some portion of the signaling pathways that get activated by $S$. typhimurium. However, $\mathrm{LXA}_{4}$ analogs did not inhibit all signals that get activated by $S$. typhimurium in T84 cells since the ability of T84 monolayers to internalize this bacterium (a process requiring many host-generated signals; 1,2 ) was not affected by $100 \mathrm{nM} 15-\mathrm{R} / \mathrm{S}$-methyl $\mathrm{LXA}_{4}$ (control monolayers internalized $0.30 \pm 0.05 \%[n=5]$ of $S$. typhimurium inoculum compared with $0.31 \pm 0.04 \%$ [ $n=5]$ for LX-treated), nor did $100 \mathrm{nM}$ 15-R/S-methyl $\mathrm{LXA}_{4}$ affect replication of S. typhimurium in vitro (data not shown) or inside T84 cells (the number of intracellular bacteria increased over a 4 -h period by a factor of $6.2 \pm 0.5$ vs. $6.4 \pm 0.6$ for control and LX-treated, respectively). Similarly, $\mathrm{LXA}_{4}$ analogs did not affect $S$. typhimurium adherence to T84 monolayers $(1.60 \pm 0.22 \%[n=5]$ of inoculum adhered to control monolayers compared with $1.59 \pm 0.10 \%$ $[n=5]$ for LX-treated). Because there are some differences in the responses of different intestinal epithelial cell lines to inflammatory stimuli $(6,22)$, we measured whether $\mathrm{LXA}_{4}$ analogs could also attenuate $S$. typhimurium-induced IL-8 secretion in other model systems. The colon-derived cell line HT29Cl19a exhibited about 10 -fold less IL-8 secretion in response to S. typhimurium than did T84 cells. This small response was inhibited by $100 \mathrm{nM} 15 \mathrm{R} / \mathrm{S}$-methyl-LXA 4 to a level below the quantitation limit of our assay ( $\geq 60 \%$ inhibition, $P<0.02$ based on comparison OD values). Ileum-derived $\mathrm{Caco} 2_{\mathrm{BBE}}$ cells exhibited about 15 -fold less IL- 8 secretion than did T84 cells. In this model system, $S$. typhimurium-induced IL-8 secretion showed a trend toward being attenuated by $15 \mathrm{R} / \mathrm{S}$ methyl-LXA $\mathrm{L}_{4}$ although we have not as yet observed statistically significant differences (59 $\pm 71 \%$ inhibition) compared with the control. Thus, although there were large differences in the absolute amounts of IL- 8 secreted by different model systems, LX attenuation of IL- 8 secretion was not restricted to a specific intestinal epithelial model.

Apical supernatants of $S$. typhimurium-infected T84 cells were assayed for PEEC, as release of this recently character- ized proinflammatory chemoattractant has been demonstrated only at that surface (8). The relative concentration of PEEC isolated from apical supernatants was assessed by two means. First, the ability of PEEC partially purified from control (vehicle) and LX-treated S. typhimurium-infected monolayers to drive PMN across virgin (i.e., not having been exposed to $S$. $t y$ phimurium or LX) epithelial monolayers was measured. $\mathrm{LXA}_{4}$ analog pretreatment of $S$. typhimurium-infected monolayers led to PEEC isolates that drove significantly fewer PMN to transmigrate (Fig. $2 a$ ), indicating that $\mathrm{LXA}_{4}$ analog-treated monolayers secreted less PEEC than control monolayers in response to S. typhimurium. Second, we measured the ability of partially purified PEEC isolates to induce cytoplasmic $\left[\mathrm{Ca}^{++}\right]$ changes in PMN, as this is a known activity of this chemoattractant (8). PEEC isolated from $\mathrm{LXA}_{4}$ analog-treated $S$. $t y$ phimurium-infected monolayers induced smaller changes in cytoplasmic $\left[\mathrm{Ca}^{++}\right]$in PMN than in PEEC isolated from control $S$. typhimurium-infected monolayers (Fig. 2 b), strengthening the suggestion that $\mathrm{LXA}_{4}$ analog treatment of epithelial cells resulted in attenuated PEEC secretion by $S$. typhimurium-infected monolayers. Because $\mathrm{LXA}_{4}$ has been shown directly to inhibit chemoattractant-induced calcium changes in PMN $(23,24)$ as well as PMN transepithelial migration (14), it is important to point out that no residual $\mathrm{LXA}_{4}$ analogs likely remained in partially purified PEEC isolates for two reasons: first, the monolayers from which PEEC was isolated were washed extensively with $\mathrm{LXA}_{4}$ analog-free buffer before col-

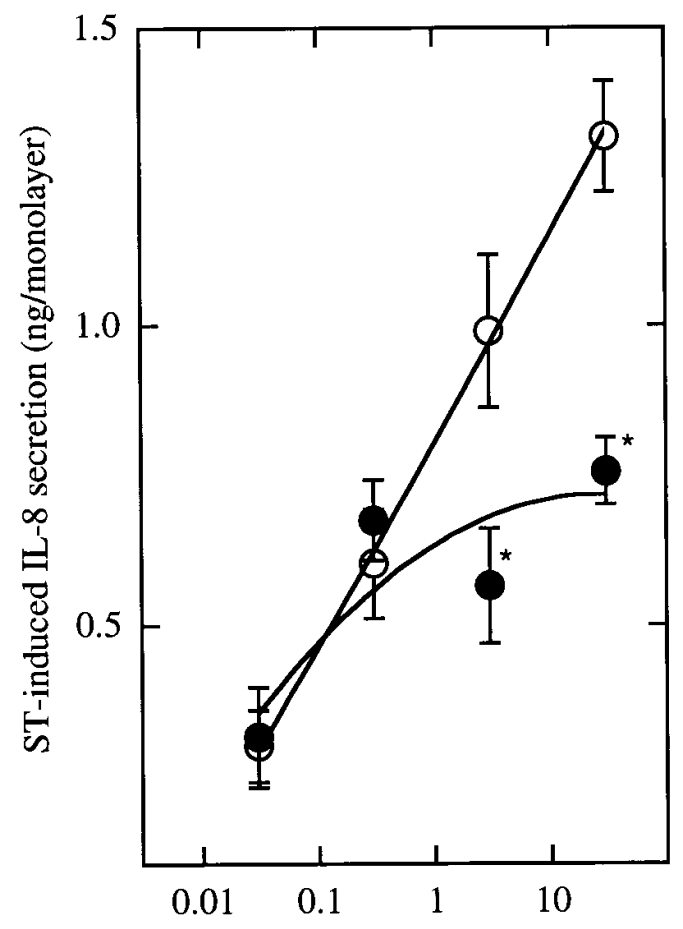

\section{Cell-associated ST (bacteria/epithelial cell)}

Figure 3. Lipoxin $\mathrm{A}_{4}$ stable analog reduces epithelial secretion of IL-8 induced by large $S$. typhimurium (ST) inoculums. Monolayers of T84 cells were incubated in $100 \mathrm{nM} 15(\mathrm{R} / \mathrm{S})$-methyl-LXA $\mathrm{LA}_{4}(\mathbf{O})$ or vehicle (O) for $1 \mathrm{~h}$ before adding $S$. typhimurium. Data are the means \pm SEM of six monolayers/condition from one experiment, and are representative of three separate experiments. 
lection of PEEC. Second, one step of the PEEC isolation procedure is collecting the filtrate from a 1,000-D nominal cutoff filter; a filter that, as expected and verified in separate experiments, does not retain statistically significant amounts of $15(\mathrm{R} /$ S)-methyl-LXA 4 (mol wt $=380.5)$.

We next sought evidence to characterize further the structural, concentration, and temporal requirements of $\mathrm{LXA}_{4}$ inhibition of $S$. typhimurium-induced IL-8 secretion. We first investigated whether $\mathrm{LXA}_{4}$ analogs might shift the dose response to $S$. typhimurium, or whether $\mathrm{LXA}_{4}$ analogs attenuated the maximal response to $S$. typhimurium. Although $\mathrm{LXA}_{4}$ analogs mildly inhibited basal IL-8 secretion by T84 monolayers (Fig. 1), $\mathrm{LXA}_{4}$ analogs did not significantly inhibit S. typhimuriuminduced (i.e., basal subtracted) IL-8 secretion in response to relatively low infectious doses of S. typhimurium (Fig. 3). Rather, $\mathrm{LXA}_{4}$ analogs attenuated this pathogen-elicited inflammatory event when the number of monolayer-associated $S$. typhimurium was one or more bacteria per epithelial cell (Fig. 3). To gain insight into the structural requirements of LX inhibition of $S$. typhimurium-induced IL-8 secretion, we investigated whether native $\mathrm{LXA}_{4}$, aspirin-triggered 15 epi-LXA stable $\mathrm{LXA}_{4}$ analogs, or lipoxin $\mathrm{B}_{4}\left(\mathrm{LXB}_{4}\right.$; displayed in Fig. 5 a) could inhibit this proinflammatory event. S. typhimurium- induced IL-8 secretion was inhibited by $\mathrm{LXA}_{4}$, 15-epi-LXA and by two stable analogs of $\mathrm{LXA}_{4}(15[\mathrm{R} / \mathrm{S}]-$ methyl-LXA 4 , 16phenoxy- $\mathrm{LXA}_{4}$ ) that have previously been shown to mimic the bioactivity of $\mathrm{LXA}_{4}(15,25,26$; Fig. 4). S. typhimurium-induced IL-8 secretion was not significantly inhibited by 15 -deoxy$\mathrm{LXA}_{4}$, a stable $\mathrm{LXA}_{4}$ analog that does not exhibit the bioactivity of the native compound (15), nor was it inhibited by $\mathrm{LXB}_{4}$ (Fig. 4), a lipoxin whose bioactivity differs in some cases from $\mathrm{LXA}_{4}(14,27,28)$, and which is not a specific ligand for the $\mathrm{LXA}_{4}$ receptor (29). The greatest level of inhibition (45士 $3.5 \%$ ) was exhibited by $15(\mathrm{R} / \mathrm{S})$-methyl- $\mathrm{LXA}_{4}$, which is both a stable analog of $\mathrm{LXA}_{4}$ and is also structurally similar to 15-epi$\mathrm{LXA}_{4}$ (see Fig. $4 a$ ). Inhibition of $S$. typhimurium-induced IL-8 secretion by $15(\mathrm{R} / \mathrm{S})$-methyl-LXA 4 was concentrationdependent (Fig. 5), exhibiting an $\mathrm{IC}_{50}$ ranging from 0.5 to $3 \mathrm{nM}$ in several different experiments, and saturable at $\sim 10 \mathrm{nM}$.

To characterize the temporal requirements of $\mathrm{LXA}_{4}$ analog inhibition of $S$. typhimurium-induced IL-8 secretion, T84 monolayers were incubated with $15(\mathrm{R} / \mathrm{S})$-methyl-LXA $\mathrm{L}_{4}$ for the indicated time intervals before colonization by $S$. typhimurium. Although $\mathrm{LXA}_{4}$ analogs inhibited basal IL-8 release (Fig. 1), an event presumably already in progress when the monolayers were exposed to $\mathrm{LXA}_{4}$ analogs, $\mathrm{LXA}_{4}$ analog inhi- a<smiles>CCCCC[C@H](O)CCCC(=O)O</smiles><smiles>CCCCC[C@H](O)/C=C/c1ccccc1</smiles>

15-epi $\mathrm{LXA}_{4}$<smiles>O=C(O)/C=C\C=C\C=C\[C@H](O)[C@H](O)CCCC(=O)O</smiles>

16-phenoxy-LXA
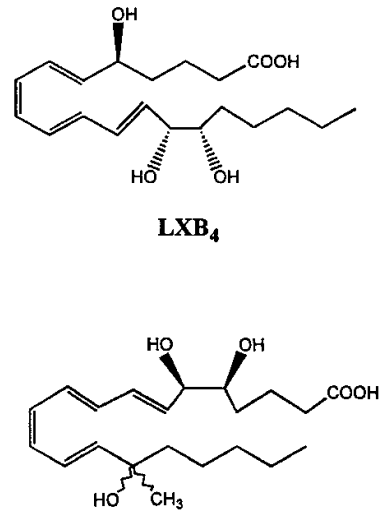

15(R/S)-methyl-LXA

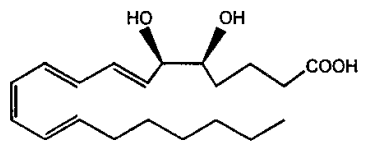

15-deoxy-LXA

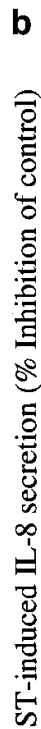

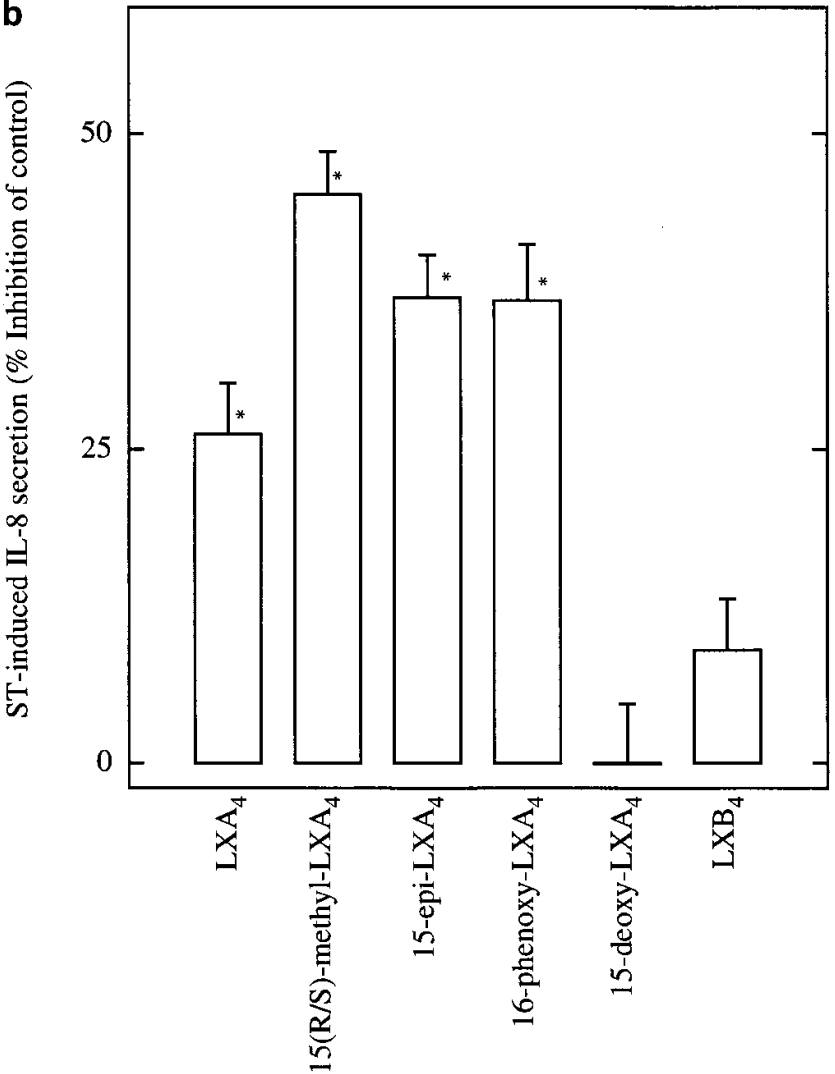

Figure 4. $\mathrm{LXA}_{4}, 15$-epi-LXA 4 , and two stable $\mathrm{LXA}_{4}$ analogs stereoselectively block $S$. typhimurium (ST)-induced IL-8 secretion by model intestinal epithelia. (a) Structure of lipoxins and lipoxin analogs used in these experiments, shown as carboxylic acids, although analogs were synthesized and used as methyl esters. Aspirin-triggered 15-epi-LXA ${ }_{4}$ differs from native $\mathrm{LXA}_{4}$ by carrying its $\mathrm{C}-15$ alcohol group in the $\mathrm{R}$ configuration.

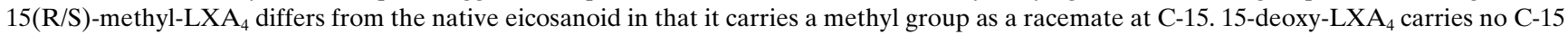
alcohol group while 16-phenoxy-LXA 4 carries a bulky substituent near the critical C-15 position. $\mathrm{LXB}_{4}$ differs from LXA $\mathrm{L}_{4}$ at several positions. (b) Monolayers of T84 cells were incubated in $100 \mathrm{nM}$ of the indicated compound or vehicle ( $0.1 \%$ ethanol) for $1 \mathrm{~h}$ before adding S. typhimurium. $5 \mathrm{~h}$ later, basolateral supernatants were assayed for IL- 8 . Data are the means \pm SEM of three separate experiments, each performed in at least quadruplicate. Results are normalized to vehicle control. 
bition of $S$. typhimurium-induced (i.e., basal subtracted) IL-8 secretion required that the T84 cells be exposed to $\mathrm{LXA}_{4}$ analogs for $1 \mathrm{~h}$ or more before infection. A typical experiment using six monolayers per condition found that cells treated with $100 \mathrm{nM} 15 \mathrm{R} / \mathrm{S}-\mathrm{methyl}_{\mathrm{LXA}}$ for $30 \mathrm{~min}$ secreted $1.14 \pm 0.15 \mathrm{ng}$ IL-8 per monolayer compared with $1.16 \pm 0.11 \mathrm{ng}$ IL-8/monolayer for vehicle-treated cells, while a 1-h treatment with this LXA $_{4}$ analog led to $S$. typhimurium-induced IL-8 secretion being $0.64 \pm 0.05 \mathrm{ng} / \mathrm{monolayer}$ compared with $1.10 \pm 0.04 \mathrm{ng} / \mathrm{mono}-$ layer for control (vehicle-treated) cells. 2-h treatment with this $\mathrm{LXA}_{4}$ analog caused $S$. typhimurium-induced IL-8 secretion to be $0.65 \pm 0.04 \mathrm{ng} /$ monolayer compared with $1.20 \pm 0.18 \mathrm{ng} /$ monolayer for the control. We then asked if monolayers that were exposed to $\mathrm{LXA}_{4}$ analogs for $1 \mathrm{~h}$ but were washed with $\mathrm{LXA}_{4}$ analog-free buffer before infection by $S$. typhimurium would still exhibit attenuated IL-8 secretion in response to this bacterium. As shown in Fig. $6 a$ (compared with Fig. $6 b$ ), LX inhibition was only partially maintained under these conditions. However, if as in Fig. $6 c, \mathrm{LXA}_{4}$ analog-treated monolayers were washed with LX-free buffer after infection by $S$. $t y$ phimurium, but still, as in Fig. $6 a$, allowing IL- 8 secretion to occur in the absence of LX, nearly full inhibition was maintained (Fig. 6, $c$ and $d$ ). These results indicate that LX need be present only during the early signaling events that lead to chemokine secretion.

To ascertain whether $\mathrm{LXA}_{4}$ analogs exhibited a general downregulatory effect on IL-8 secretion, or was specific to $S$.

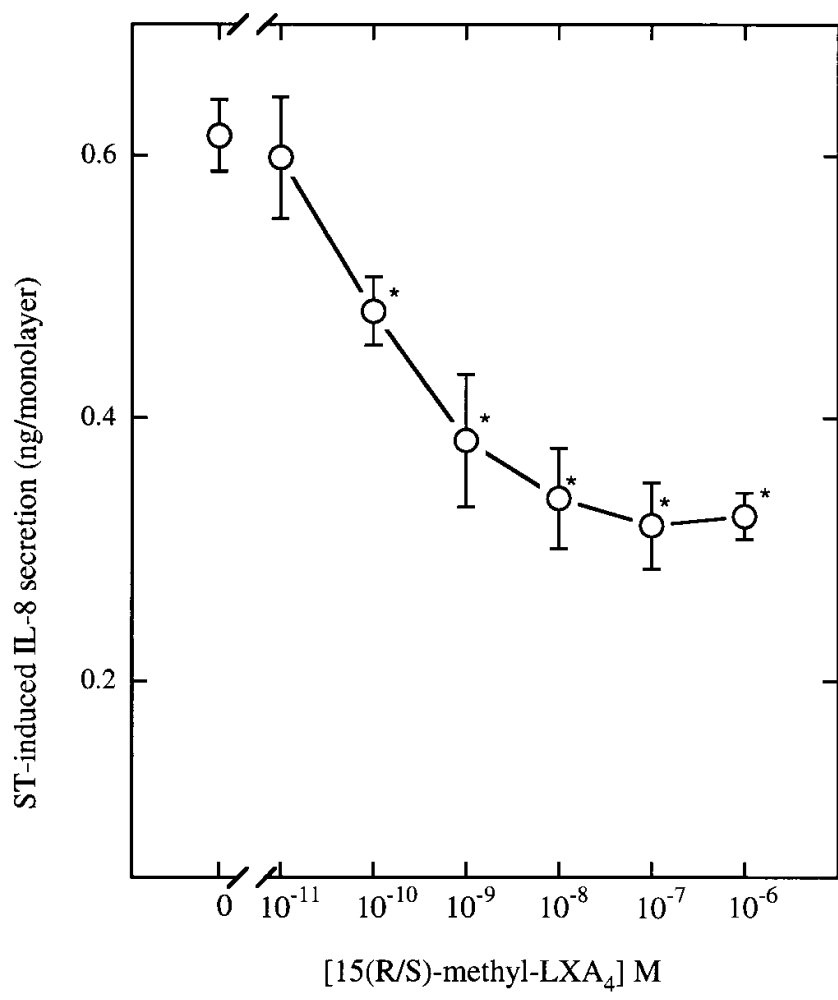

Figure 5. Concentration-dependence of inhibition of S. typhimurium-induced IL- 8 secretion by stable $\mathrm{LXA}_{4}$ analog. Monolayers of T84 cells were incubated with indicated concentrations of $15(\mathrm{R} / \mathrm{S})$ methyl-LXA ${ }_{4}$ for $1 \mathrm{~h}$ before adding $S$. typhimurium. $5 \mathrm{~h}$ later, basolateral supernatants were assayed for IL-8. Data are the means \pm SEM of six monolayers/condition from one experiment, and are representative of four separate experiments. typhimurium, we measured whether $\mathrm{LXA}_{4}$ analogs could also inhibit IL-8 secretion induced by other physiological agonists. The noninvasive bacteria EPEC also elicits IL-8 secretion, albeit 5-10-fold less than $S$. typhimurium, presumably by a somewhat different mechanism (17). We found that EPECinduced IL-8 secretion could also be inhibited by $\mathrm{LXA}_{4}$ ana$\operatorname{logs}(0.14 \pm 0.06$ vs. $0.06 \pm 0.03 \mathrm{ng} /$ monolayer for vehicle-treated and $100 \mathrm{nM} 15-\mathrm{R} / \mathrm{S}$-methyl-LXA ${ }_{4}$-treated, respectively; $P<$ 0.05). Furthermore, the ability of LX to inhibit stimulus-induced IL-8 secretion was not limited to bacteria, as IL-8 secretion induced by TNF $\alpha$ could also be attenuated by an $\mathrm{LXA}_{4}$ analog (monolayers treated for $1 \mathrm{~h}$ with vehicle or $100 \mathrm{nM} 15 \mathrm{R} / \mathrm{S}$ methyl-LXA 4 before stimulation with $10 \mathrm{ng} / \mathrm{ml} \mathrm{TNF} \alpha$ secreted $0.42 \pm 0.04$ vs. $0.26 \pm 0.03 \mathrm{ng} / \mathrm{monolayer}$, respectively; $P<0.05$ ). Interestingly, IL-8 secretion induced by saturating concentra-

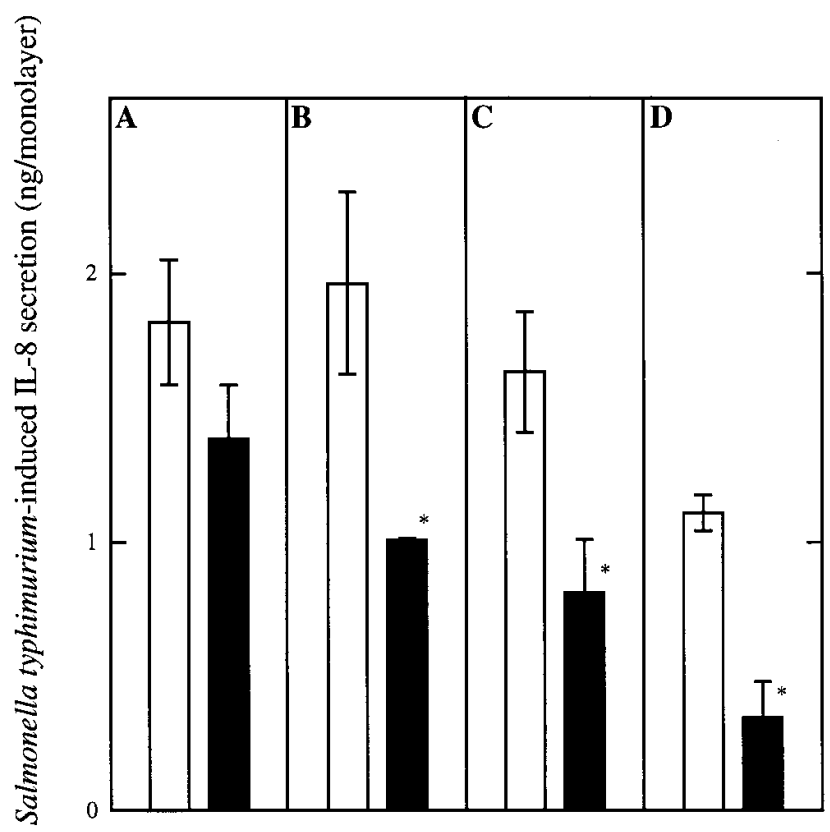

Figure 6. Incubating T84 monolayers in LX-free buffer after S. typhimurium colonization does not affect LX-inhibition of S. typhimurium-induced IL-8 secretion. Monolayers of T84 cells were incubated with vehicle (open bars) or $100 \mathrm{nM} 15(\mathrm{R} / \mathrm{S}$ )-methyl-LXA 4 (solid bars) for $1 \mathrm{~h}$ before adding $S$. typhimurium. $5 \mathrm{~h}$ after adding $S$. typhimurium, basolateral supernatants were assayed for IL-8. Note that the differences in control values between different panels, particularly the lower control value in $D$, are due to supernatants being collected over a shorter time interval as washing out LX also washed out any IL- 8 that had been secreted before that point. Data are the means \pm SEM of six monolayers/condition from one experiment, and are representative of three separate experiments. $(A)$ Monolayers were washed $3 \times$ with LX-free HBSS before adding bacteria. After adding S. typhimurium, monolayers were placed, and chemokine secretion was allowed to occur into fresh HBSS that contained no LX. $(B)$ Monolayers were never washed after adding LX. Rather, monolayers were placed, and chemokine secretion was allowed to occur into the LX-containing HBSS in which the cells had incubated before adding S. typhimurium. (C) Monolayers were washed free of LX $1 \mathrm{~h}$ after adding bacteria. After being washed, monolayers were placed, and chemokine secretion was allowed to occur into fresh HBSS that contained no LX. $(D)$ Monolayers were washed free of LX $2 \mathrm{~h}$ after adding bacteria. After being washed, monolayers were placed, and chemokine secretion was allowed to occur into fresh HBSS that contained no LX. 
tions of $\mathrm{TNF} \alpha(>25 \mathrm{ng} / \mathrm{ml})$ was not significantly affected by $\mathrm{LXA}_{4}$ analogs (data not shown). To begin to elucidate the mechanism by which LX attenuate IL- 8 secretion, we measured whether LX affected levels of IL-8 mRNA. Basal IL-8 mRNA was not detectable by Northern blot analysis. $2 \mathrm{~h}$ after exposure to $S$. typhimurium, IL-8 mRNA increased to detectable levels and continued to increase during the next $3 \mathrm{~h}$. IL-8 mRNA levels were $\sim 50 \%$ lower in $\mathrm{LXA}_{4}$ analog-treated T84 monolayers compared with vehicle-treated controls (Fig. 7), correlating with our measurements of IL-8 secretion. These results indicate that $\mathrm{LXA}_{4}$ analog attenuation of chemokine secretion is mediated at the mRNA level.

Having established that $\mathrm{LXA}_{4}$ analogs could partially inhibit epithelial secretion of these proinflammatory chemokines that drive PMN movement, we next investigated whether this inhibition was sufficient to lead to attenuated PMN movement in response to $S$. typhimurium. S. typhimurium-infected polarized epithelial monolayers drive PMN placed near their basolateral surface to move across the epithelium to the apical surface, but do not drive PMN placed near their apical surface to migrate to the basolateral surface, thereby mimicking $S$. typhi-

vehicle $(0.1 \%$ ethanol) + Salmonella typhimurium
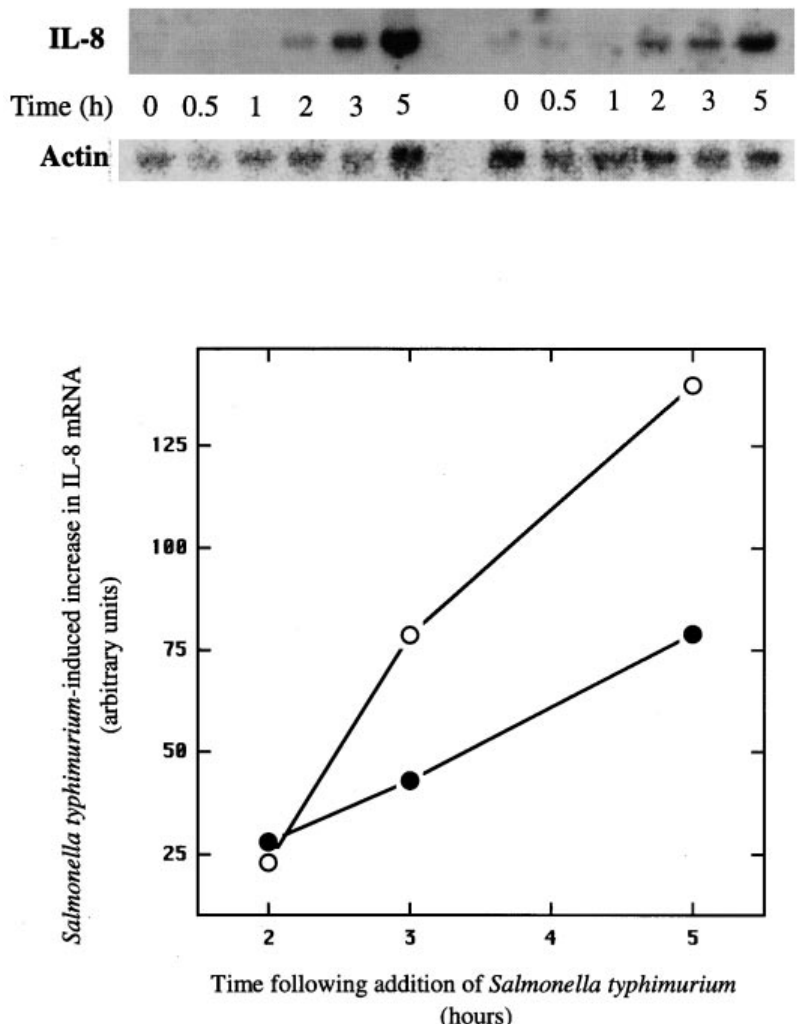

Figure 7. IL-8 mRNA levels in S. typhimurium-infected T84 monolayers are lower in cells treated with a $\mathrm{LXA}_{4}$ stable analog. T84 monolayers $\left(5 \mathrm{~cm}^{2}\right)$ were treated with $100 \mathrm{nM} 15 \mathrm{R} / \mathrm{S}$-methyl-LXA 4 for $1 \mathrm{~h}$ before adding S. typhimurium. At the indicated time point after adding the bacteria, RNA was extracted, and IL-8 mRNA (and in a second hybridization to the same membrane actin mRNA) was analyzed by Northern blot. IL-8 mRNA was quantitated by densitometry and normalized relative to actin mRNA levels. This experiment was performed twice, and similar results were obtained both times. $(O)$ Vehicle-treated control; $(\bullet)+100 \mathrm{nM}$ 15(R/S)-methyl-LXA . murium infection in vivo where PMN are driven to the intestinal lumen (3). IL-8 has been shown to be largely responsible for directing PMN through the basolateral extracellular matrix (lamina propria) of model epithelia in response to S. typhimurium (7). As shown in Fig. $8 a, \mathrm{LXA}_{4}$ and an $\mathrm{LXA}_{4}$ analog inhibited $S$. typhimurium-induced movement of PMN through T84 matrices, indicating that one consequence of LX inhibition of IL- 8 secretion was reduced PMN movement to a subepithelial compartment. Once PMN have migrated through the subepithelial matrix, their migration across the epithelium in response to $S$. typhimurium is driven, at least in large part, by PEEC (8). S. typhimurium-induced PMN transepithelial migration was attenuated by nanomolar concentrations of $15(\mathrm{R} /$ $\mathrm{S}$ )-methyl-LXA 4 (Fig. $8 \mathrm{~b}$ ), indicating that, analogously to the above, $\mathrm{LXA}_{4}$ inhibition of PEEC secretion resulted in clear attenuation of PMN transepithelial migration.

\section{Discussion}

Biosynthesis of LX in vivo appears to be one means by which inflammation is self-limited (10). While some of the antiinflammatory effects of LX can be explained by LX acting directly on the neutrophil, LX may also act directly on other cell types, thus providing an additional mechanism by which LX can modulate inflammation (e.g., $\mathrm{LXA}_{4}$ stable analogs have recently been shown to act directly on vascular endothelium; 30). Since epithelial cells play an important role in mediating inflammation at mucosal surfaces, we speculated that epithelium could be an additional site of antiinflammatory action of this class of eicosanoids. Consistent with this hypothesis, we have shown here that LX inhibited both basal and pathogenelicited secretion of proinflammatory chemokines by model intestinal epithelia. This suppression was unlikely the result of a general inhibition of LX on the function of epithelial cells, as neither epithelial uptake of bacteria nor PMA-induced IL-8 secretion was affected by LX. Reduced PMN movement across model epithelia in response to infection by the enteric pathogen $S$. typhimurium was an important consequence of LX inhibition of epithelial chemokine secretion. Such transepithelial migration of PMN appears to play a role in producing symptoms associated with intestinal inflammation (31). However, before this report there was no defined means (other than generally cytotoxic approaches such as global inhibition of protein synthesis) of inhibiting secretion of the proinflammatory chemokines that direct PMN movement. Hence, the demonstration that LX can downregulate epithelial secretion of pro-inflammatory chemokines suggests a potential therapeutic strategy for active intestinal inflammation.

It seems likely that the observed actions of lipoxins on epithelial chemokine secretion were mediated by the $\mathrm{LXA}_{4}$ receptor: a seven-transmembrane $\alpha$-helix G-protein-linked receptor that mediates the actions of $\mathrm{LXA}_{4}, 15$-epi-LXA stable $\mathrm{LXA}_{4}$ analogs on PMN and monocytes $(25,29)$. Consistent with this notion, it has recently been established that intestinal epithelial cell lines express this receptor (32), and the observed $\mathrm{IC}_{50}$ values were similarly supportive of $\mathrm{LXA}_{4}$ receptor-mediated actions. Although native $\mathrm{LXA}_{4}$ competes somewhat more effectively for the $\mathrm{LXA}_{4}$ receptor than do the

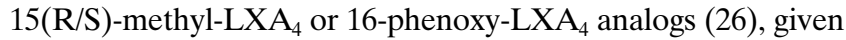
the stability of these $\mathrm{LXA}_{4}$ analogs it is not surprising that they provide greater attenuation of $S$. typhimurium-induced epithelial IL-8 secretion than the native eicosanoid. 15-deoxy- 
$\mathrm{LXA}_{4}$, which lacks a carbon 15 alcohol, did not exhibit antiinflammatory behavior in the model system used here or in others tested previously (15), consistent with both the earlier suggestion that the trihydroxytetraene structure is required for bioactivity, and the likely role of the $\mathrm{LXA}_{4}$ receptor in mediating the antiinflammatory actions of $\mathrm{LXA}_{4}$ analogs.

Ligation of the $\mathrm{LXA}_{4}$ receptor was found to attenuate chemokine secretion in an agonist-specific fashion. For example, while IL- 8 secretion induced by pathogens $S$. typhimurium or EPEC were reduced, IL-8 secretion induced by the strong protein kinase $\mathrm{C}$ agonist PMA was not affected by lipoxins. Hence, in contrast to protein kinase $\mathrm{C}$ activation, signaling cascades initiated by pathogens likely selectively interface with $\mathrm{LXA}_{4}$ receptor-mediated signaling cascades (neither the pathogen-activated or the $\mathrm{LXA}_{4}$ receptor-signaling cascades are currently understood). Furthermore, given the suggestion that $S$. typhimurium may induce an increase in cytoplasmic $\left[\mathrm{Ca}^{++}\right]$ upon attachment to eukaryotic cells (33), we also examined the influence of thapsigargin (which causes a release of $\mathrm{Ca}^{++}$from intracellular stores) on the responses observed. Thapsigargin also stimulated IL-8 secretion in the absence of pathogens, however, such chemokine secretion was again not affected by $\mathrm{LXA}_{4}$ stable analogs (data not shown). Lastly, we observed that LX-mediated attenuation of $S$. typhimurium-induced chemokine secretion was best detected when T84 cells were exposed to LX for $1 \mathrm{~h}$ or more before adding bacteria. Keeping in mind that $S$. typhimurium-induced chemokine secretion takes several hours to become maximal, possible explanations for the temporal requirements of LX action include the following: (a) the $\mathrm{LXA}_{4}$ receptor-mediated signaling cascade involves protein synthesis; (b) LX induces epithelial synthesis of another eicosanoid or other mediating product that attenuates chemokine secretion; or (c) LX -induced signals are transduced by a somewhat slow mechanism.

Most nonsteroidal antiinflammatory agents act by inhibiting enzymes that make, or receptors that recognize, proinflammatory eicosanoids. In contrast, $\mathrm{LXA}_{4}$ stable analogs appear to attenuate epithelial cell secretion of proinflammatory chemokines by activating receptor-mediated pathways that naturally downregulate inflammation. Furthermore, $\mathrm{LXA}_{4}$ receptor-mediated antiinflammatory effects may more tightly focus on counterregulation of inflammation than do other
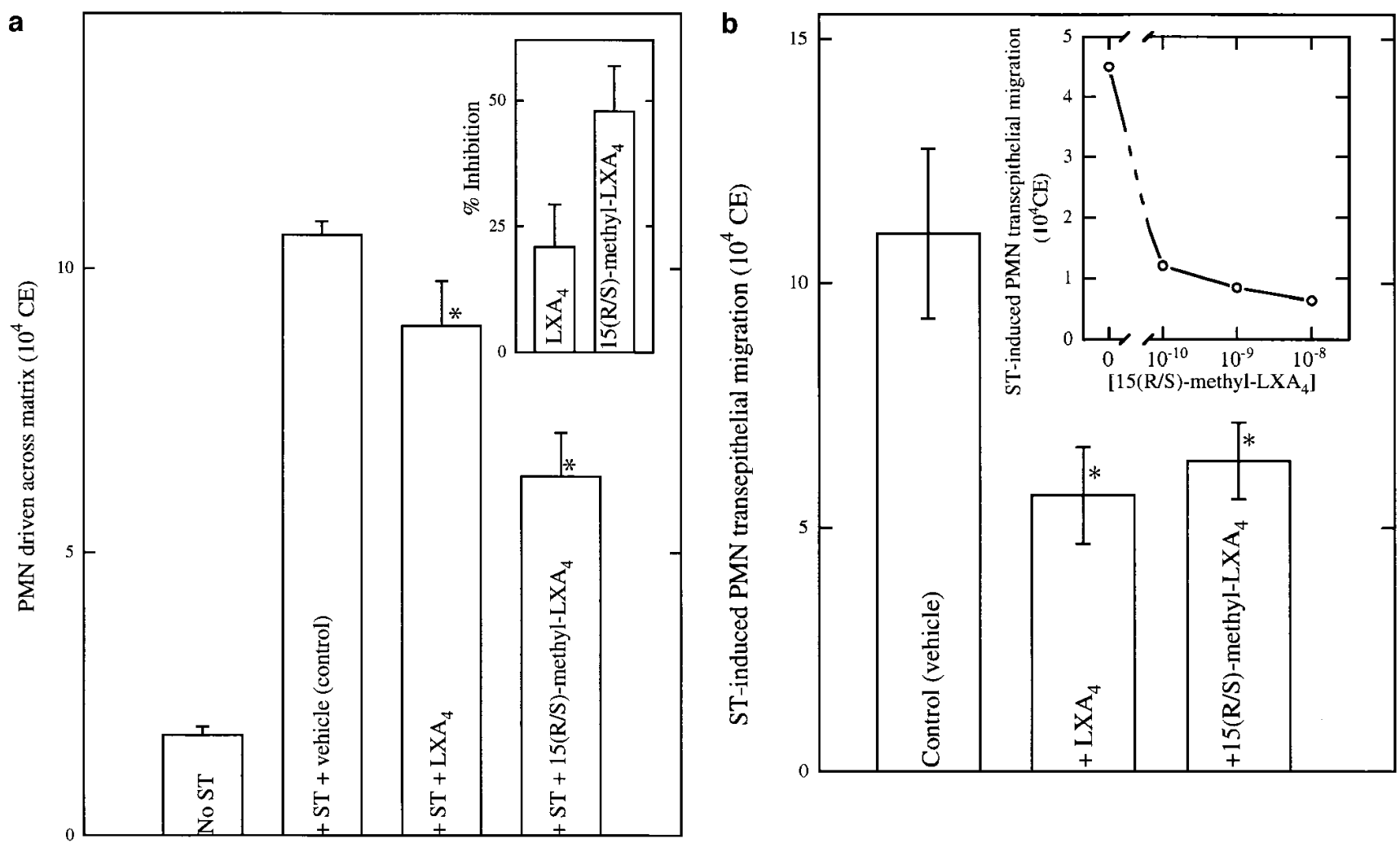

Figure 8. $\mathrm{LXA}_{4}$ stable analog treatment of epithelial monolayer leads to attenuated PMN migration. $(A)$ Inverted monolayers of T84 cells were

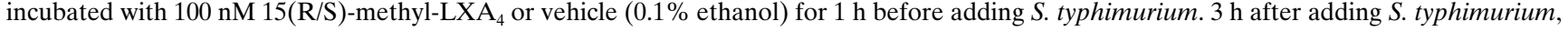
T84 cells were removed from their underlying matrices by treatment with EGTA. The abilities of the matrices (which remain attached to the collagen-coated filters on which the cells were grown) to drive PMN movement was assessed by placing PMN upon them and measuring how many were driven through the matrix in the physiologically relevant direction. Data are the means \pm SEM of four monolayers/condition from one experiment, and are representative of three separate experiments. Inset shows this data expressed as percent inhibition of control response. $(B)$ Inverted monolayers of T84 cells were incubated with $15(\mathrm{R} / \mathrm{S})$-methyl-LXA $4(1 \mathrm{nM}$, indicated concentration in inset $)$ or vehicle $(0.1 \%$ ethanol $)$ for $1 \mathrm{~h}$ before adding $S$. typhimurium. $1 \mathrm{~h}$ after adding $S$. typhimurium, monolayers were washed three times in HBSS to remove nonadherent bacteria (and presumably LX), and were placed into fresh HBSS that contained no LX. PMN were then placed in the apical reservoir, and PMN transepithelial migration to the basolateral reservoir was measured. Data in main panel are the means \pm SEM of four monolayers/condition of a single experiment, and are representative of three separate experiments. Data in inset are the means of a representative experiment performed in triplicate. 
nonsteroidal antiinflammatory compounds. For example, it is known that aspirin, via its effects on prostaglandin H synthase-1, diminishes prostaglandin synthesis, and it is recognized that prostaglandins are necessary for maintening epithelial barrier function in the mucosa of the alimentary tract (34). Thus, depletion of mucosal prostaglandins leads to surface erosions, resulting in direct tissue exposure to the complex and noxious content of the gut lumen. Interestingly, it has recently been recognized that aspirin-mediated acetylation of prostaglandin $\mathrm{H}$ synthase-2 results in production of a unique agonist for the $\mathrm{LXA}_{4}$ receptor 15-epi-LXA (16). 15-epi-LXA $_{4}$ displays the bioactivities of other active lipoxin stable analogs (15) including, as shown here, inhibition of agonist-induced release of epithelial proinflammatory cytokines. Thus, it is likely that aspirin exposure results in counterbalancing injurious (diminished prostaglandin synthesis) and antiinflammatory (including production of a stable $\mathrm{LXA}_{4}$ receptor ligand) effects on intestinal mucosa. If so, direct activation of the $\mathrm{LXA}_{4}$ receptor would seemingly permit a more targeted antiinflammatory approach to diseases of the intestinal mucosa characterized by active inflammation.

Although proinflammatory chemokines are known to drive the immune inflammatory response, methods of inhibiting their release have not been established. Here, we establish one such method in a physiologically relevant context; i.e., inhibition of chemokine release using nanomolar concentrations of analogs of an eicosanoid that is produced by humans. Furthermore, LX attenuation of chemokine secretion sufficient to lead to attenuated epithelial orchestration of PMN movement described here was observed in response to a known gastroenterological pathogen that induces neutrophil movement as part of its virulence mechanism (5). Thus, direct inhibition of epithelial proinflammatory signaling cascades by LX represents a potential means of therapeutic intervention in such disease states. The overall effect of LX on inflammation may even be greater than that measured on chemokine secretion alone, since LX also directly affects PMN by downregulating their response to chemoattractants $(19,20)$. Adding further to the therapeutic potential of LX stable analogs is the possibility that downregulating chemokine secretion in this manner may be part of the mechanism by which inflammation is normally locally contained.

\section{Acknowledgments}

We thank Dr. Elizabeth Simons of Boston University for use of the spectrofluorometer. These studies were supported by National Institutes of Health grants DK-47662 (J.L. Madara), DK-35932 (J.L. Madara), DK-50989 (B. McCormick), GM-38765 (C.N. Serhan), and a discovery grant from Schering AG (J.L. Madara, C.N. Serhan, and N.A. Petasis). A.T. Gewirtz is supported by an individual National Research Service Award. K. Gronert is a postdoctoral fellow of the Arthritis Foundation.

\section{References}

1. Galan, J.E., and C. Ginocchio. 1994. The molecular basis of Salmonella entry into mammalian cells. Biochem. Soc. Trans. 22:301-306.

2. Finlay, B.B. 1995. Interaction between Salmonella typhimurium, enteropathogenic Escherichia coli (EPEC), and host epithelial cells. Adv. Dent. Res. 9: 3-36.

3. McCormick, B.A., S.P. Colgan, C.D. Archer, S.I. Miller, and J.L. Madara. 1993. Salmonella typhimurium attachment to human intestinal epithelial monolayers: transcellular signaling to subepithelial neutrophils. J. Cell. Biol. 123:895-907.

4. Eckmann, L., M. Kagnoff, and J. Fierer. 1993. Epithelial cells secrete the chemokine interleukin-8 in response to bacterial entry. Infect. Immun. 61:45694574.

5. McCormick, B.A., S.I. Miller, D. Carnes, and J.L. Madara. 1995. Transepithelial signaling to neutrophils by Salmonellae: a novel virulence mechanism for gastroenteritis. Infect. Immun. 63:2302-2309.

6. Jung, H.C., L. Eckmann, S.-K. Yang, A. Panja, J. Fierer, E. MorzyckaWroblewska, and M.F. Kagnoff. 1995. A distinct array of proinflammatory cytokines is expressed in human colon epithelial cells in response to bacterial invasion. J. Clin. Invest. 95:55-65.

7. McCormick, B.A., P.M. Hofman, J. Kim, D.K. Carnes, S.I. Miller, and J.L. Madara. 1995. Surface attachment of Salmonella typhimurium to intestinal epithelia imprints the subepithelial matrix with gradients chemotactic for neutrophils. J. Cell. Biol. 131:1599-1608.

8. McCormick, B.A, C.A. Parkos, S.P. Colgan, D.K. Carnes, and J.L Madara. Apical secretion of a pathogen-elicited epithelial chemoattractant (PEEC) activity in response to surface colonization of intestinal epithelia by Salmonella typhimurium. J. Immunol. 160:455-466.

9. Lewin, K.J, R.H. Riddel, and W.M. Weinstein. 1992. Inflammatory bowel diseases. In Gastrointestinal Pathology and its Clinical Implications. IgakuShoin Ltd., New York. 812-990.

10. Serhan, C.N. 1997. Lipoxins and novel aspirin-triggered 15-epi-lipoxins (ATL): a jungle of cell-cell interactions or a therapeutic opportunity? Prostaglandins. 53:107-137.

11. Raud, J., U. Palmertz, S.E. Dahlen, and P. Hedqvist. 1991. Lipoxins inhibit microvascular inflammatory actions of leukotriene B4. Adv. Exp. Med. Biol. 314:185-192.

12. Dahlen, S.E., L. Franzen, J. Raud, C.N. Serhan, P. Westlund, E. Wikstrom, T. Bjorck, H. Matsuda, S.E. Webber, C.A. Veale, et al. 1988. Actions of lipoxin A4 and related compounds in smooth muscle preparations and on the microcirculation in vivo. Adv. Exp. Med. Biol. 229:107-130.

13. Papayianni, A., S. Takata, C.N. Serhan, and H.R. Brady. 1993. Counterregulatory actions of leukotrienes and lipoxins on P-selectin expression on human endothelial cell adhesion. J. Am. Soc. Nephrol. 4:627.

14. Colgan, S.P., C.N. Serhan, C.A. Parkos, C. Delp-Archer, and J.L. Madara. 1993. Lipoxin A4 modulates transmigration of human neutrophils across intestinal epithelial monolayers. J. Clin. Invest. 92: 75-82.

15. Serhan, C.N., J.F. Maddox, N.A. Petasis, I. Akritopoulou-Zanze, A. Papayianni, H.R. Brady, S.P. Colgan, and J.L. Madara. 1995. Design of lipoxin A4 stable analogs that block transmigration and adhesion of human neutrophils. Biochemistry. 34:14609-14615.

16. Claria, J., and C.N. Serhan. 1995. Aspirin triggers previously undescribed bioactive eicosanoids by human endothelial cell-leukocyte interactions. Proc. Natl. Acad. Sci. USA. 92:9475-9479.

17. Savkovic, S.D., A. Koutsouris, and G. Hecht. 1996. Attachment of a non-invasive pathogen, enteropathogenic Eschericia coli, to cultured human intestinal epithelial monolayers induces transmigration of neutrophils. Infect. Immun. 64:4480-4487.

18. Parkos, C.A., C. Delp, M.A. Arnaout, and J.L. Madara. 1991. Neutrophil migration across a cultured intestinal epithelium: dependence on a CD1lb/ CD18-mediated event and enhanced efficiency in the physiologic direction. $J$. Clin. Invest. 88:1605-1612.

19. Gewirtz, A.T., and E.R. Simons. 1997. Phospholipase D mediates Fcy receptor activation of neutrophils and provides signaling specificity between signaling pathways activated by fMLP and HIC. J. Leukocyte Biol. 61:131-138.

20. Brunkhorst, B.A., K.G. Lazzari, G.R. Strohmeier, G. Weil, and E.R. Simons. 1991. Calcium changes in immune complex-stimulated human neutrophils: simultaneous measurement of receptor occupancy and activation reveals full population stimulus binding but subpopulation activation. J. Biol. Chem. 266:13035-13043

21. Read, M.A., A.S. Neish, F.W. Luscinskas, V.J. Palombella, T. Maniatis, and T. Collins. 1995. The proteosome pathway is required for cytokine-induced endothelial-leukocyte adhesion molecule expression. Immunity. 2:493-506.

22. Eckmann, L., H.-C. Jung, C.-C. Schuerer-Maly, A. Panja, E. MorzyckaWroblewska, and M.F. Kagnoff. 1993. Differential cytokine expression by human intestinal epithelial cell lines: regulated expression of interleukin-8. Gastroenterology. 105:1689-1697.

23. Lee, T.H., C.E. Horton, U. Kyan-Aung, D. Haskard, A.E. Crea, and B.W. Spur. 1989. Lipoxin A4 and lipoxin B4 inhibit chemotactic responses of human neutrophils stimulated by leukotriene B4 and N-formyl-L-methionylL-leucyl-L-phenylalanine. Clin. Sci. 77:195-203.

24. Grandordy, B.M., H. Lacroix, E. Mavoungou, S. Krilis, A.E. Crea, B.W. Spur, and T.H. Lee. 1990. Lipoxin A4 inhibits phosphoinositide hydrolysis in human neutrophils. 167:1022-1029.

25. Maddox, J.F., M. Hachicha, T. Takano, N.A. Petasis, V.V. Fokin, and C.N. Serhan. 1997. Lipoxin A4 stable analogs are potent mimetics that stimulate human monocytes and THP-1 cells via a G-protein-linked lipoxin A4 receptor. J. Biol. Chem. 272:6972-6978.

26. Takano, T., S. Fiore, J.F. Maddox, H.R. Brady, N.A. Petasis, and C.N. Serhan. 1997. Aspirin-triggered 15-epi-lipoxin A4 and LXA4 stable analogs are 
potent inhibitors of acute inflammation: evidence for anti-inflammatory receptors. J. Exp. Med. 185:1693-1704.

27. Romano, M., J.F. Maddox, and C.N. Serhan. 1996. Activation of human monocytes and the acute monocytic leukemia cell line (THP-1) by lipoxins involves unique signaling pathways for lipoxin A4 versus lipoxin B4: evidence for differential $\mathrm{Ca}^{2+}$ mobilization. J. Immunol. 157:2149-2154.

28. Tamaoki, J., E. Tagaya, I. Yamawaki, and K. Konno. 1995. Lipoxin A4 inhibits cholinergic neurotransmission through nitric oxide generation in the rabbit trachea. Eur. J. Pharmacol. 287:233-238.

29. Fiore, S., M. Romano, E. Reardon, and C.N. Serhan. 1993. Induction of functional lipoxin A4 receptors in HL-60 cells. Blood. 81:3395-3403.

30. Scalia, R., J. Gefen, N.A. Petasis, C.N. Serhan, and A.M. Lefer. 1997. Lipoxin $\mathrm{A}_{4}$ stable analogs inhibit leukocyte rolling and adherence in the rat mes- enteric microvasculature: role of P-selectin. Proc. Natl.. Acad. Sci. USA. 94: 9967-9972.

31. Madara, J.L., S. Nash, and C. Parkos. 1991. Neutrophil-epithelial cell interactions in the intestine. In Cell-Cell Interactions and the Release of Inflammatory Mediators. P. Wong and C. Serhan, editors. Plenum Publishing Corp., New York.

32. Gronert, K., Gewirtz, A.T., Madara, J.L., and Serhan, C.N. 1998. Identification of a human enterocyte lipoxin $\mathrm{A}_{4}$ receptor that is regulated by IL-13 and INF- $\gamma$ that inhibits TNF $\alpha$-induced IL-8 release. J. Exp. Med. In press.

33. Pace, J., M.J. Hayman, and J.E. Galan. 1993. Signal transduction and invasion of epithelial cells by S. typhimurium. Cell. 72:505-514.

34. Hawkey, C.J. 1997. Non-steroidal anti-inflammatory drug gastropathy: causes and treatment. Scand. J. Gastroenterol. 31(Suppl. 220):124-127. 